\title{
OBESITY IS ASSOCIATED WITHLACK OF ACCESS TO DENTAL CARE AND PHYSICAL ACTIVITY AMONG OLDER ADULTS: A CROSS-SECTIONAL STUDY
}

\section{Obesidade está associada com falta de acesso a serviços odontológicos e atividade física em idosos: um estudo transversal}

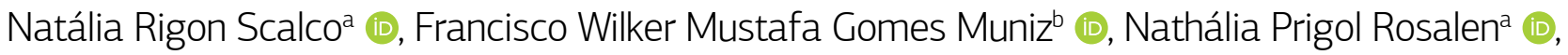

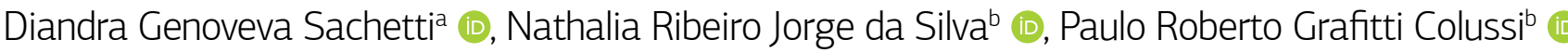

OBJECTIVE: This study evaluated the prevalence of obesity and associated factors among older adults. METHODS: This was a household-based cross-sectional study involving 282 individuals aged $\geq 60$ years recruited in the city of Veranópolis, Brazil, using random probabilistic sampling. Participants underwent a clinical oral examination and completed a structured questionnaire. Obesity was determined based on body mass index (BMI). Individuals were divided into two groups based on the presence $\left(\mathrm{BMl} \geq 30 \mathrm{~kg} / \mathrm{m}^{2}\right)$ or absence of obesity $\left(\mathrm{BMl}<30 \mathrm{~kg} / \mathrm{m}^{2}\right)$. Uni- and multivariate analyses were performed using Poisson regression with robust variance. RESULTS: The prevalence of obesity was 34\% ( $n=96)$. Each 1-year increase in age resulted in a 3.09\% decrease in the likelihood of being classified as having obesity (prevalence ratio [PR] = 0.969; 95\% confidence interval [95\%Cl] 0.949 - 0.989). Older adults that reported walking $<5$ or $\geq 5$ times per week were 39.65 and $37.20 \%$ less likely to be classified as obese. The PRs of obesity in former and non-smokers were 4.40 and 5 times higher, respectively, than in current smokers $(p<0.05)$. Older adults with no access to dental care were $51.72 \%(p=0.013)$ more likely to present with obesity. CONCLUSIONS: There was a high prevalence of obesity among older adults. Obesity was associated with lower age, smoking status, no access to dental care, and a lack of physical activity. KEYWORDS: aging; epidemiology; obesity; oral health.

OBJETIVO: O presente estudo avaliou a prevalência de obesidade e fatores associados em idosos. METODOLOGIA: Um estudo transversal domiciliar, com amostragem probabilística, foi realizado com 282 indivíduos de idade $\geq 60$ anos de Veranópolis, Brasil. Um exame clínico de saúde bucal foi realizado e um questionário estruturado foi aplicado. A obesidade foi determinada pelo Índice de Massa Corporal (IMC). Os indivíduos foram categorizados com obesidade (IMC $\geq 30 \mathrm{~kg} / \mathrm{m}^{2}$ ) e sem obesidade (IMC $\left.<30 \mathrm{~kg} / \mathrm{m}^{2}\right)$. Análises uni e multivariadas foram feitas por meio de regressão de Poisson com variância robusta. RESULTADOS: A prevalência de obesidade foi de 34\% ( $n$ = 96). Cada ano de aumento na idade resultou em uma diminuição de 3,09\% (razão de prevalência $[R P]=0,969$; intervalo de confiança de 95\% [IC95\%] = 0,949 - 0,989) na RP de ser do grupo de obesos. Idosos que reportaram caminhar < cinco ou $\geq$ cinco vezes por semana apresentaram menor RP para obesidade, 39,65 e 37,20\%, respectivamente. Ex-fumantes e não fumantes obtiveram, respectivamente, 4,40 e 5 vezes maior RP de serem do grupo de obesos quando comparados aos fumantes ( $p<0,05)$. Idosos sem acesso a serviços odontológicos demonstraram 51,72\% $(p=0,013)$ maior RP de serem do grupo com obesidade. CONCLUSÕES: Houve uma alta prevalência de obesidade em idosos, que foi associada com menor idade, estado de fumo e ausência de acesso ao dentista e atividade física.

PALAVRAS-CHAVE: envelhecimento; epidemiologia; obesidade; saúde bucal.

aUniversidade Federal de Passo Fundo - Passo Fundo (RS), Brazil.

bUniversidade Federal de Pelotas - Pelotas (RS), Brazil.

Correspondence data

Francisco Wilker Mustafa Gomes Muniz - Rua Gonçalves Chaves, 457 - Centro - CEP: 96015560 - Pelotas (RS), Brazil. E-mail: wilkermustafa@gmail. com @Wilkermustafa

Received on: 11/16/2020. Accepted on: 02/18/2021

How to cite this article: Muniz FWMG, Scalco NR, Rosalen NP, Sachetti DG, Silva NRJ, Colussi PRG. Obesity is associated with lack of access to the dentist and physical activity among older adults: cross-sectional study. Geriatr Gerontol Aging. 2021;15:e0210008. https://doi.org/10.5327/Z2447-212320212000143 https://doi.org/10.5327/Z2447-212320212000143 


\section{INTRODUCTION}

Obesity is an important public health issue whose prevalence has increased across all age groups in recent years, both in developed and developing countries such as Brazil., ${ }^{1,2} \mathrm{It}$ is a complex, multifactorial, and largely preventable disease, and over $30 \%$ of the global population is estimated to be either overweight or obese. ${ }^{3}$ In Brazil, most studies report a prevalence of 25 to $30 \%$ for obesity in older adults..$^{4-6}$

The pathogeneses of obesity are not completely understood. However, it seems to involve a complex relationship between biological, psychosocial, and behavioral factors, including genetic, socioeconomic, and cultural characteristics. ${ }^{7}$ Moreover, obesity is considered a risk factor for numerous chronic non-communicable illnesses, such as cardiovascular disease, hypertension, and diabetes mellitus, ${ }^{1,8}$ which is especially concerning for older adults. Furthermore, the high health costs associated with obesity represent a serious public health problem. ${ }^{9}$

According to the literature, low income and education levels are directly related to poorer health and a higher risk of obesity, and this inequality tends to increase with age. ${ }^{10}$ These associations may be attributable to differences in access to health care, healthier diet choices, regular physical activity, and other parameters related to a healthy lifestyle.

The assessment of obesity and other conditions that affect older adults is important for public health planning. Its high prevalence and constant increase demonstrate that the few existing government interventions aimed at these issues have not been effective. ${ }^{11}$ In this sense, the present study aimed to assess the prevalence of obesity and associated factors in older adults in a southern Brazilian city.

\section{METHODS}

\section{Study design and location}

This was a household-based cross-sectional study involving interviews and assessments of individuals aged 60 years and older living in the urban and rural areas of Veranópolis, Rio Grande do Sul, Brazil. Veranópolis has a population of approximately 22810 individuals. ${ }^{12}$ This figure includes 3554 adults aged 60 years or older. Males comprise 42.91\% of the population, while females account for the remaining $57.09 \%$. A total of $87 \%$ of the population lives in urban areas. In 2010, the Municipal Human Development Index for Veranópolis was $0.75 .{ }^{13}$ Its GDP per capita was $\mathrm{R} \$ 41184.25$ and its 2010 Gini coefficient was $0.4836 .{ }^{14}$ Life expectancy at birth in Veranópolis is 75.24 years, and the illiteracy rate for people aged 15 years and older is $2.82 \% .{ }^{15}$ The present study was reviewed and approved by the Research Ethics Committee of the Universidade de Passo Fundo, under protocol No.\#2 990 088. All eligible individuals read and signed an informed consent document before entering the study.

Sample size calculation and sampling strategy

Sample size was estimated based on the prevalence of obesity in older adults, as reported in a previous study. ${ }^{6}$ A 5\% attrition rate was added to this figure, resulting in a required sample of 278 older adults. Probabilistic cluster sampling was used to select 278 participants, 242 in urban and 36 in rural areas to reflect the proportion of urban to rural population in the area. A map of the city was used to number all blocks in the urban area. Eighty-two blocks (20\% of total blocks) were then randomly selected for participation in the study using the website www.random.org. Three households were visited in each block, and all those with at least one older resident were selected for inclusion. Additionally, the corners of the blocks were numbered from one to four and a random draw was used to determine the starting point for the first interview. Once the first interview was complete, additional households were visited in a clockwise manner until the third interview was complete. When the number of older adults in one of the selected blocks was below the minimum required sample size, new blocks were selected for the study. Participants were also recruited in 3 randomly selected rural communities in the region. In each community, data were collected from 12 households with at least one older resident. The sampling of rural households included homes in the central area of the community as well as those located along access roads.

\section{Inclusion and exclusion criteria}

The inclusion criteria adopted in this study were individuals aged 60 years and older living in the sampling regions. All those with no physical, medical, or mental conditions that prevented them from taking part in the study or understand the examinations and interviews were eligible to participate. If during initial contact, the researcher observed that an individual would be unable to take part in the study, or their caregiver informed that they could not participate, they were excluded from the sample. If more than one resident in a household met eligibility criteria, all were invited to participate in the study. Additionally, the sample was limited to one household per apartment building. If the home was empty at the time of data collection, a new visit was made at a later date. Visitors to the household were not eligible to participate in the study. Long-term care institutions, commercial establishments, and vacant houses were not surveyed. 


\section{Clinical examination and interview}

A structured questionnaire was used to collect sociodemographic and behavioral data, while patients' medical and dental histories were investigated using sections of the PCATool-Brasil. ${ }^{16}$ Obesity was determined based on body mass index (BMI), following the criteria set by the World Health Organization (WHO). BMI was calculated as weight $(\mathrm{kg}) /$ height $\left(\mathrm{m}^{2}\right) .{ }^{17}$ Weight was measured using an $\mathrm{EKS}^{\circledast}$ electronic scale (Kowloon, Hong Kong) with a maximum capacity of $200 \mathrm{Kg}$. Height was measured in an upright position with a wall-mounted stadiometer (WISO ${ }^{\circledR}$, São José, Brazil) accurate to the nearest $\mathrm{cm}$.

Physical activity (PA) was assessed using the short version of the International Physical Activity Questionnaire (IPAQ), which has been validated for use in Brazil. ${ }^{18}$ The short version of the IPAQ provides a weekly estimate of the time spent in moderate and vigorous physical activity, as well as the time spent walking and sitting. ${ }^{19}$

Oral health was assessed by tooth count and by the use of and need for a dental prosthesis. This examination was carried out using a wooden spatula, without artificial lighting or the aid of mouth mirrors. The tooth count did not include third molars. Individuals were examined and interviewed from December 2018 to January 2019 by teams composed of an interviewer, an oral health examiner, and an examiner responsible for the anthropometric measurements, all of whom had been trained by the study coordinators to ensure a standardized assessment.

Training consisted of participation in theory classes, discussions of all items in the questionnaire, and information about oral health exams and anthropometric measurements. Before the study, data collectors also practiced these skills by administering the questionnaire and performing oral health examinations and anthropometric measurements in older adults treated in the clinics of the Faculty of Dentistry of Universidade de Passo Fundo. Intra-examiner and inter-examiner reliability of the oral health examination was verified by conducting a second assessment 14 days after the initial examination. This procedure involved $5 \%$ of the original sample, chosen by a random draw. Kappa coefficients for intra-examiner and inter-examiner reliability were greater than 0.89 for all oral health variables.

\section{Statistical analysis}

The dependent variable in the present study was the prevalence of obesity as defined by WHO criteria. ${ }^{17}$ Individuals were categorized into two groups based on BMI $\geq 30 \mathrm{~kg} / \mathrm{m}^{2}$ and BMI $<30 \mathrm{~kg} / \mathrm{m}^{2}$. Independent variables in the present study included: age (in years), race/ethnicity, education, marital status, area of residence, retirement status, health problems, use of medication, number of walks in a week, smoking status, alcohol use, access to dental care, missing teeth, use of and need for dental prosthesis.

Sex was categorized as male or female. Race/ethnicity was classified as white or non-white (ie, older adults who identified as black, yellow, brown, or indigenous). Educational level was categorized as low (illiterate or complete elementary education); medium (complete or incomplete high school); or high (complete or incomplete higher education). Marital status was classified as married or unmarried (including widowed, single, and divorced). The area of residence was determined to be urban or rural based on data and maps provided by the City Hall of Veranópolis. Retirement status was divided into three groups: not retired; retired, not working; and retired, still working.

Health problems were determined based on the self-reported absence or unawareness of health issues ("no") vs presence or awareness of a health problem ("yes"). Use of medication was classified according to the use of one or more medications ("yes") vs no medication use ("no").IPAQ data on the weekly frequency of walking were used to divide participants into the following categories: no walking, for those who reported no physical activity; $<5$ for those who reported taking one to four walks per week; and $\geq 5$ for people who walked five times or more. Only continuous 10-minute walks were considered.

With regard to smoking status, participants were classified as non-smokers, current smokers, and former smokers. Alcohol use was assessed based on whether participants reported consuming alcohol frequently or moderately. Those who did so were classified as users, while those who did not were considered non-users. Access to dental care in the last 12 months was dichotomized as "yes" or "no."Use of a dental prosthesis was dichotomized in a similar manner, with participants who used at least one fixed prosthesis, a removable partial prosthesis, or a total prosthesis were considered prosthesis users. Need for prosthesis was also categorized as “yes" or "no."Individuals who needed partial or complete oral rehabilitation in at least one arch were considered to need prosthetic treatment.

Data analysis was performed using SPSS 21 (SPSS Inc., Chicago, United States). Associations between dependent and independent variables were presented as frequency distributions and assessed using chi-square or Mann-Whitney tests. The level of significance was 5\%. Uni- and multivariate analyses were performed using Poisson regression with robust variance to verify the association between dependent and independent variables. In the multivariate model, only variables with $p<0.20$ in univariate analysis were included. Independent variables were retained in the final model based on significance $(p<0.05)$ and impact on effect sizes. Multicollinearity analysis showed no significant associations between independent variables. 


\section{RESULTS}

A total of 282 older adults were interviewed and examined. Results showed that 244 (86.52\%) participants were from urban areas and 38 (13.47\%) were from rural areas, as described in Figure 1. There was no missing data for any of the variables studied. The prevalence of obesity was $34 \%(n=96)$. Sex was significantly associated with obesity (Table 1 ).

Table 2 shows the univariate analysis of the association between obesity and the independent variables. For a 1-year increase in age, the probability of being classified as obese decreased by $2.16 \%$ (Prevalence ratio [PR] $=0.98$; $95 \%$ confidence interval $[95 \% \mathrm{CI}] 0.96-0.99)$. Likewise, sex was associated with obesity, with women being $63.31 \%(\mathrm{p}=0.03$ ) more likely than men to be classified as obese.

The initial multivariate model included the following variables: age, sex, health problems, physical activity, smoking status, and access to dental care. Table 3 shows the final multivariate analysis for the association between obesity and the independent variables. With every 1 -year increase in age, the probability of being classified as obese decreased by $3.09 \%(\mathrm{PR}=0.97 ; 95 \% \mathrm{CI} 0.95-0.99)$. Individuals who went on $<5$ or $\geq 5$ walks per week were 39.65 and $37.20 \%$ less likely, respectively, to be classified as obese relative to those who did not walk at all. Formersmokers and non-smokers had PRs of 4.400 (95\%CI 1.26 15.37) and 5.00 (95\%CI $1.48-16.97)$, respectively, relative to current smokers. Similarly, individuals without access to dental care were $51.72 \%(\mathrm{p}=0.01)$ more likely to be classified as obese when compared to those with access to dental care in the last 12 months.

\section{DISCUSSION}

The present study aimed to assess the prevalence of obesity and associated factors among older adults in a city in southern Brazil. The results demonstrated a high prevalence of obesity, which was associated with lower age, lack of physical activity, smoking status, and lack of access to dental care. The assessment of obesity in older adults is important, as it addresses a major public health problem, and can influence the healthy aging process.

Our results indicate an urgent need for multidisciplinary approaches to reduce the prevalence and burden of high BMI among older adults. ${ }^{8}$ This is particularly challenging for a country with significant socioeconomic inequality, such as Brazil. ${ }^{12}$ In the present study, the prevalence of obesity according to WHO criteria was 34\%. These results are in accordance with those of a previous study, where the prevalence of obesity was approximately $40 \% .{ }^{20}$ However, some studies have estimated the prevalence of obesity in Brazil to be closer to $50 \% .^{21}$ The country is following the worldwide trend of increasing prevalence of obesity and chronic diseases in older adults, as has been observed in several countries in recent decades. ${ }^{22}$
Number of households visited (urban and rural): 284

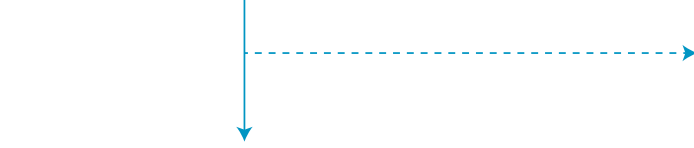

Number of households included: 256

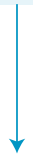

Number of households visited in urban area: 225

207 households with 1 older adult 17 households with 2 older adults 1 household with 3 older adults

Number of participants from urban area: 244
Number of households that refused to participate in the study: 28
Number of households visited in rural area: 31

24 households with 1 older adult 7 households with 2 older adults

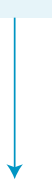

Number of participants from rural area: 38

Figure 1. Flow chart depicting participant selection, Veranópolis (RS), Brazil, 2019. 
Age was associated with obesity in the present study, with advancing age showing an association with decreased prevalence. This trend has been observed in previous studies..$^{20,23}$ Our results also show that advancing age may be indicative of an even greater decrease in physical activity, which is natural to the aging process itself. ${ }^{24}$ Reasons for this may include physical limitations, fear of falling, pain, unwillingness to exercise, and insecurity. ${ }^{25}$ Moreover, aging promotes important changes in muscle mass and body fat distribution, increasing the proportion of abdominal fat. ${ }^{23}$ The association of age and abdominal obesity may be partially explained by factors such as a natural decline in growth hormones, basal metabolic rate, and physical activity. ${ }^{26}$ All of these factors may explain the results detected in the present study.

Our findings also showed an association between obesity and an absence of physical activity. Older adults who engaged in weekly physical activity had a lower PR for obesity. The literature identifies physical inactivity as one

Table 1. Demographic characteristics of the sample and frequency of obesity among the elderly, Veranópolis (RS), Brazil, 2019.

\begin{tabular}{|c|c|c|c|c|}
\hline Variable & & $\begin{array}{l}\text { Without obesity } \\
\text { BMI < } 30 \mathrm{~kg} / \mathrm{m}^{2} \\
(\mathrm{n}=186 ; 66 \%)\end{array}$ & $\begin{array}{l}\text { With obesity } \\
\text { BMI } \geq 30 \mathrm{~kg} / \mathrm{m}^{2} \\
\text { (n = 96; 34\%) }\end{array}$ & p-value \\
\hline Age & Years & $72.08 \pm 8.34$ & $70.15 \pm 6.82$ & $0.11 \#$ \\
\hline Sex & $\begin{array}{c}\text { Male - n (\%) } \\
\text { Female - n (\%) }\end{array}$ & $\begin{array}{c}62(33.33) \\
124(66.67)\end{array}$ & $\begin{array}{l}19(19.79) \\
77(80.21)\end{array}$ & $0.02^{*}$ \\
\hline Race/ethnicity & $\begin{array}{c}\text { White - n (\%) } \\
\text { Non-white - n (\%) }\end{array}$ & $\begin{array}{c}168(90.32) \\
18(9.68)\end{array}$ & $\begin{array}{l}84(87.50) \\
12(12.50)\end{array}$ & $0.47^{*}$ \\
\hline Level of Education & $\begin{array}{l}\text { Low - n (\%) } \\
\text { Medium - n (\%) } \\
\text { High - n (\%) }\end{array}$ & $\begin{array}{l}147(79.03) \\
22(11.83) \\
17(9.14)\end{array}$ & $\begin{array}{c}78(81.25) \\
13(13.54) \\
5(5.21)\end{array}$ & $0.49 *$ \\
\hline Marital status & $\begin{array}{c}\text { Married - n (\%) } \\
\text { Non-married - n (\%) }\end{array}$ & $\begin{array}{l}98(52.68) \\
88(47.32)\end{array}$ & $\begin{array}{l}52(54.16) \\
44(45.84)\end{array}$ & $0.81^{*}$ \\
\hline Area of residence & $\begin{array}{l}\text { Urban - n (\%) } \\
\text { Rural - n (\%) }\end{array}$ & $\begin{array}{l}161(86.56) \\
25(13.44)\end{array}$ & $\begin{array}{l}83(86.46) \\
13(13.54)\end{array}$ & $0.98^{*}$ \\
\hline Retirement status & $\begin{array}{l}\quad \text { Not retired }-\mathrm{n}(\%) \\
\text { Retired, not working }-\mathrm{n}(\%) \\
\text { Retired, still working }-\mathrm{n}(\%)\end{array}$ & $\begin{array}{c}22(11.83) \\
117(62.90) \\
47(25.27)\end{array}$ & $\begin{array}{l}11(11.46) \\
66(68.75) \\
19(19.79)\end{array}$ & $0.56^{*}$ \\
\hline Health problems & $\begin{array}{l}\text { Yes - n (\%) } \\
\text { No - n (\%) }\end{array}$ & $\begin{array}{l}160(86.02) \\
26(13.98)\end{array}$ & $\begin{array}{c}88(91.67) \\
8(8.33)\end{array}$ & $0.17^{*}$ \\
\hline Medication use & $\begin{array}{l}\text { Yes - n (\%) } \\
\text { No - n (\%) }\end{array}$ & $\begin{array}{l}158(84.95) \\
28(15.05)\end{array}$ & $\begin{array}{c}87(90.63) \\
9(9.37)\end{array}$ & $0.18^{*}$ \\
\hline Number of walks in a week & $\begin{array}{l}\text { None }-\mathrm{n}(\%) \\
1 \text { to } 4-\mathrm{n}(\%) \\
\geq 5-\mathrm{n}(\%)\end{array}$ & $\begin{array}{l}66(35.48) \\
58(31.18) \\
62(33.34)\end{array}$ & $\begin{array}{l}47(48.96) \\
23(23.96) \\
26(27.08)\end{array}$ & $0.09 *$ \\
\hline Smoking status & $\begin{array}{c}\text { Smokers - n (\%) } \\
\text { Former-smokers - n (\%) } \\
\text { Non-smokers - n (\%) }\end{array}$ & $\begin{array}{c}18(9.67) \\
45(24.19) \\
123(66.14)\end{array}$ & $\begin{array}{c}2(2.08) \\
23(23.96) \\
71(73.96)\end{array}$ & $0.06^{*}$ \\
\hline Alcohol use & $\begin{array}{l}\text { Yes - n (\%) } \\
\text { No - n (\%) }\end{array}$ & $\begin{array}{l}100(53.76) \\
86(46.24)\end{array}$ & $\begin{array}{l}56(58.33) \\
40(41.67)\end{array}$ & $0.47^{*}$ \\
\hline Access to dental care & $\begin{array}{l}\text { Yes - n (\%) } \\
\text { No - n (\%) }\end{array}$ & $\begin{array}{l}93(50) \\
93(50)\end{array}$ & $\begin{array}{l}38(39.58) \\
58(60.42)\end{array}$ & $0.10^{*}$ \\
\hline Missing teeth & Mean \pm SD & $20.47 \pm 9.45$ & $21.19 \pm 8.48$ & $0.78 \#$ \\
\hline Use of dental prosthesis & $\begin{array}{l}\text { Yes - n (\%) } \\
\text { No - n (\%) }\end{array}$ & $\begin{array}{c}23(12.37) \\
163(87.63)\end{array}$ & $\begin{array}{l}13(13.54) \\
83(86.46)\end{array}$ & $0.77^{*}$ \\
\hline Need for dental prosthesis & $\begin{array}{l}\text { Yes - n (\%) } \\
\text { No - n (\%) }\end{array}$ & $\begin{array}{l}132(70.97) \\
54(29.03)\end{array}$ & $\begin{array}{l}74(77.08) \\
22(22.92)\end{array}$ & $0.27^{*}$ \\
\hline
\end{tabular}

\#Mann-Whitney; ${ }^{*} \chi^{2}$ test; SD: standard deviation. 
Table 2. Univariate analysis of the association between obesity and exploratory variables among the elderly, Veranópolis (RS), Brazil, 2019.

\begin{tabular}{|c|c|c|c|}
\hline Variable & & Prevalence ratio $(95 \% \mathrm{Cl})$ & p-value \\
\hline Age & In years & $0.98(0.96-0.99)$ & 0.04 \\
\hline Sex & $\begin{array}{l}\text { Male } \\
\text { Female }\end{array}$ & $\begin{array}{c}\text { Ref. } \\
1.63(1.06-2.51)\end{array}$ & 0.03 \\
\hline Race/ethnicity & $\begin{array}{l}\text { White } \\
\text { Non-white }\end{array}$ & $\begin{array}{c}\text { Ref. } \\
1.20(0.75-1.92)\end{array}$ & 0.45 \\
\hline Level of education & $\begin{array}{l}\text { Low } \\
\text { Medium } \\
\text { High }\end{array}$ & $\begin{array}{c}\text { Ref. } \\
1.07(0.67-1.71) \\
0.67(0.30-1.45)\end{array}$ & $\begin{array}{l}0.77 \\
0.30\end{array}$ \\
\hline Marital status & $\begin{array}{c}\text { Married } \\
\text { Non-married }\end{array}$ & $\begin{array}{c}\text { Ref. } \\
0.96(0.69-1.33)\end{array}$ & 0.81 \\
\hline Area of residence & $\begin{array}{l}\text { Urban } \\
\text { Rural }\end{array}$ & $\begin{array}{c}\text { Ref. } \\
1.01(0.63-1.62)\end{array}$ & 0.98 \\
\hline Retirement status & $\begin{array}{c}\text { Not retired } \\
\text { Retired } \\
\text { Retired and working }\end{array}$ & $\begin{array}{c}\text { Ref. } \\
1.08(0.64-1.82) \\
0.86(0.47-1.60)\end{array}$ & $\begin{array}{l}0.77 \\
0.64\end{array}$ \\
\hline Health problems & $\begin{array}{l}\text { Yes } \\
\text { No }\end{array}$ & $\begin{array}{c}\text { Ref. } \\
0.66(0.35-1.24)\end{array}$ & 0.20 \\
\hline Medication use & $\begin{array}{l}\text { Yes } \\
\text { No }\end{array}$ & $\begin{array}{c}\text { Ref. } \\
0.69(0.38-1.24)\end{array}$ & 0.21 \\
\hline Number of walks in a week & $\begin{array}{l}\text { None } \\
1 \text { to } 4 \\
\geq 5\end{array}$ & $\begin{array}{c}\text { Ref. } \\
0.68(0.45-1.03) \\
0.71(0.48-1.05)\end{array}$ & $\begin{array}{l}0.07 \\
0.09\end{array}$ \\
\hline Smoking status & $\begin{array}{c}\text { Smokers } \\
\text { Former-smokers } \\
\text { Nonsmokers }\end{array}$ & $\begin{array}{c}\text { Ref. } \\
3.38(0.87-13.13) \\
3.66(0.97-13.81)\end{array}$ & $\begin{array}{l}0.08 \\
0.06\end{array}$ \\
\hline Alcohol use & $\begin{array}{l}\text { Yes } \\
\text { No }\end{array}$ & $\begin{array}{c}\text { Ref. } \\
0.88(0.64-1.23)\end{array}$ & 0.47 \\
\hline Access to dental care & $\begin{array}{l}\text { Yes } \\
\text { No }\end{array}$ & $\begin{array}{c}\text { Ref. } \\
1.32(0.95-1.85)\end{array}$ & 0.10 \\
\hline Missing teeth & & $1.01(0.99-1.02)$ & 0.53 \\
\hline Use of dental prosthesis & $\begin{array}{l}\text { Yes } \\
\text { No }\end{array}$ & $\begin{array}{c}\text { Ref. } \\
1.07(0.67-1.71)\end{array}$ & 0.78 \\
\hline Need for dental prosthesis & $\begin{array}{l}\text { Yes } \\
\text { No }\end{array}$ & $\begin{array}{c}\text { Ref. } \\
1.24(0.84-1.85)\end{array}$ & 0.29 \\
\hline
\end{tabular}

Table 3. Multivariate analysis of the association between obesity and exploratory variables in the elderly, Veranópolis (RS), Brazil, 2019.

\begin{tabular}{|c|c|c|c|}
\hline \multicolumn{2}{|l|}{ Variable } & \multirow{2}{*}{$\begin{array}{c}\text { Prevalence ratio }(95 \% \mathrm{Cl}) \\
0.97(0.95-0.99)\end{array}$} & \multirow{2}{*}{$\begin{array}{l}\text { p-value } \\
<0.01\end{array}$} \\
\hline Age & & & \\
\hline Number of walks in a week & $\begin{array}{l}\text { None } \\
1 \text { to } 4 \\
\geq 5\end{array}$ & $\begin{array}{c}\text { Ref. } \\
0.60(0.41-0.90) \\
0.63(0.43-0.92)\end{array}$ & $\begin{array}{l}0.01 \\
0.02\end{array}$ \\
\hline Smoking status & $\begin{array}{l}\text { Smokers } \\
\text { Former-smokers } \\
\text { Non-smokers }\end{array}$ & $\begin{array}{c}\text { Ref. } \\
4.40(1.26-15.37) \\
5.00(1.48-16.97)\end{array}$ & $\begin{array}{l}0.02 \\
0.01\end{array}$ \\
\hline Access to dental care & $\begin{array}{l}\text { Yes } \\
\text { No }\end{array}$ & $\begin{array}{c}\text { Ref. } \\
1.52(1.09-2.11)\end{array}$ & 0.01 \\
\hline
\end{tabular}


of the main risk factors for all-cause mortality. ${ }^{27}$ This can also be observed in studies that point to a sedentary lifestyle or physical inactivity as risk factors for obesity. ${ }^{4,23,28}$ Moreover, the maintenance of physical activity throughout the life-course is associated with a lower prevalence of chronic diseases in older adulthood. ${ }^{29}$ Unfortunately, the prevalence of physical inactivity is high among older adults in Brazil, ranging from 47 to $70 \% .^{24,25}$ The high prevalence of physical inactivity and its harmful effects on health highlight the need for strategies to increase physical activity, which are known to be effective; this situation should be a public health priority, especially for vulnerable groups such as older adults. ${ }^{30}$

In the present study, non-smokers and former smokers had a higher PR for obesity when compared to smokers. A similar result was found in a study conducted in another city ${ }^{6}$ corroborating previous findings in the literature. ${ }^{4,5}$ Individuals who smoke are less likely to present with obesity, as components of cigarettes, including nicotine, can interfere with hunger and satiety mechanisms, in addition to increasing the basal metabolic rate. ${ }^{31}$ Moreover, studies show that smoking cessation results in increased body weight in both men and women, with approximately $75 \%$ of smokers gaining weight when abstinent. ${ }^{32}$ The literature also reports a significant impact of the number of cigarettes consumed per day and length of smoking cessation on obesity. ${ }^{33}$ However, these variables were not measured in this investigation, which may constitute a limitation of the present study.

Sex and education were not associated with obesity in the present study, replicating the findings observed in another city of Rio Grande do Sul. ${ }^{6}$ However, several studies show a trend towards a higher BMI in women than men. ${ }^{10,28} \mathrm{~A}$ possible explanation for this is the difference in body build between men and women, which BMI does not capture. Moreover, factors such as menopause are known to increase visceral fat accumulation. ${ }^{21}$ Similarly, the literature demonstrates a clear association between obesity and socioeconomic status, especially for those with lower income and education levels. ${ }^{28}$ Education is a major contributor to better diet quality, which is also associated with a higher cost. ${ }^{34}$ Additionally, high levels of education are related to better health behaviors, such as regular physical activity and frequent medical consultations. It is important to highlight that, in comparison with other cities in the state of Rio Grande do Sul, Veranópolis has a high purchasing power, which, in part, may explain the results of the present study.

It may be that the costs of dental care and difficulty in accessing health care services may be among the main causes of infrequent dental visits. Indirectly, these results may explain the higher PR of obesity in people with no access to dental care. Although lack of access to dental care has been associated with obesity in older adults, this has not been the case for oral health. In the present study, the number of remaining teeth was not associated with obesity. However, there is evidence to support the correlation between the number of remaining teeth and obesity. ${ }^{35}$ Some studies also demonstrate an association between obesity and a worse oral health status, especially an unmet need for prosthodontic treatment and nutritional risk. ${ }^{36}$ It may be hypothesized that different patterns of food choice can be affected both by the absence of teeth and lack of adequate oral rehabilitation.

This study has some limitations. Its cross-sectional design does not allow for the determination of causal associations between obesity and exploratory variables. We also did not test the masticatory efficiency of older adults who used dental prosthetics or needed oral rehabilitation. In addition, there was a lack of information on the number of cigarettes consumed or the period of smoking cessation. Furthermore, since individuals with any physical, medical, and mental impairments were excluded from the present study, our findings may have limited applicability to older adults with these conditions.

\section{CONCLUSION}

Our findings showed a high prevalence of obesity in older adults. Obesity was associated with younger age, lack of physical activity, smoking, and access to dental care.

\section{CONFLICTS OF INTEREST}

The authors declare no conflicts of interest.

\section{FUNDING}

This work was supported in part by the Coordenação de Aperfeiçoamento de Pessoal de Nível Superior (CAPES) Finance Code 001.

\section{AUTHORS' CONTRIBUTION}

NRS: data curation, investigation, visualization, writing - original draft. FWMGM: conceptualization, formal analysis, methodology, software, writing — original draft. NPR: data curation, investigation, writing - review \& editing. DGS: investigation, writing — review \& editing. NRJS: formal analysis, visualization, writing — original draft. PRGC: conceptualization, funding acquisition, investigation, methodology, writing — review \& editing. 


\section{REFERENCES}

1. Malta DC, Andrade SC, Claro RM, Bernal RTI, Monteiro CA. Trends in prevalence of overweight and obesity in adults in 26 Brazilian state capitals and the Federal District from 2006 to 2012. Rev Bras Epidemiol. 2014;17(Suppl. 1):267-76. https://doi.org/10.1590/18094503201400050021

2. Kalish VB. Obesity in older adults. Prim Care. 2016;43(1):137-44. https://doi.org/10.1016/j.pop.2015.10.002

3. Hruby A, Hu FB. The epidemiology of obesity: a big picture. Pharmacoeconomics. 2015;33(7):673-89. https://dx.doi. org/10.1007\%2Fs40273-014-0243-x

4. Costa CD, Schneider BC, Cesar JA. General and abdominal obesity among the elderly from Southern Brazil: results of the HOW ARE YOU DOING? (COMO VAI?) study. Ciên Saúde Coletiva. 2016:21(11):358596. https://doi.org/10.1590/1413-812320152111.02492016

5. Andrade FB, Caldas Junior AF, Kitoko PM, Batista JEM, Andrade TB. Prevalence of overweight and obesity in elderly people from Vitória-ES, Brazil. Ciên Saúde Coletiva. 2012;17(3):749-56. https:// doi.org/10.1590/S1413-81232012000300022

6. Pizolotto R, Muniz FWMG, Stoffel L, Amorim ANH, Colussi PRG, Rösing CK, et al. Obesity is not associated with oral variables in the elderly: a population-based cross-sectional study. Rev Bras Obes Nutr Emagr. 2019;13(83 Suppl. 1):1044-53.

7. Apovian CM. Obesity: definition, comorbidities, causes, and burden. Am J Manag Care. 2016;22(7 Suppl.):s176-85.

8. Afshin A, Forouzanfar MH, Reitsma MB, Sur P, Estep K, Lee A, et al. Health Effects of Overweight and Obesity in 195 Countries over 25 Years. N Engl J Med. 2017;377(1):13-27. https://doi.org/10.1056/ nejmoa1614362

9. Nilson EAF, Andrade RDCS, Brito DA, Oliveira ML. Costs attributable to obesity, hypertension, and diabetes in the Unified Health System, Brazil, 2018. Rev Panam Salud Publica. 2020;44:e32. https://doi. org/10.26633/RPSP.2020.32

10. Raeisi A, Mehboudi M, Darabi H, Nabipour I, Larijani B, Mehrdad $\mathrm{N}$, et al. Socioeconomic inequality of overweight and obesity of the elderly in Iran: Bushehr Elderly Health (BEH) Program. BMC Public Health. 2017;17(1):72. https://doi.org/10.1186/s12889016-3912-1

11. Dietz WH. The response of the US Centers for Disease Control and Prevention to the obesity epidemic. Annu Rev Public Health. 2015;36:575-96. https://doi.org/10.1146/annurevpublhealth-031914-122415

12. Instituto Brasileiro de Geografia e Estatística. Censo Demográfico 2010: Características da população e domicílios - resultados gerais. Rio de Janeiro: Instituto Brasileiro de Geografia e Estatística; 2011.

13. Instituto Brasileiro de Geografia e Estatística. Índice de Desenvolvimento Humano, 2010. Brasília: Instituto Brasileiro de Geografia e Estatística; 2010.

14. Brasil. Ministério da Saúde. Porto Alegre 2010 [cited on 2019 Dec 1th]. Available from: http://tabnet.datasus.gov.br/cgi/ibge/censo/ cnv/ginirs.def.

15. Rio Grande do Sul. Fundação de Economia e Estatística. Perfil socioeconômico dos municípios 2010. Rio Grande do Sul; 2010.

16. Brasil. Ministério da Saúde. Manual do Instrumento de Avaliação da Atenção Primária à Saúde: PCATool-Brasil. Brasília: Ministério da Saúde; 2010.

17. World Health Organization. Obesity: preventing and managing the global epidemic. Report of a WHO consultation. World Health Organization; 2000. 253 p.

18. Matsudo S, Araújo T, Matsudo V, Andrade D, Andrade E, Oliveira LC, et al. International Physical Activity Questionnaire (IPAQ): study of validity and reliability in Brazil. Ativ Física Saúde. 2001;6(2): 5-18. https://doi.org/10.12820/rbafs.v.6n2p5-18

19. Benedetti T, Antunes P, Rodriguez-Añez C, Mazo GZ, Petroski EL. Reprodutibilidade e validade do Questionário Internacional de Atividade Física (IPAQ) em homens idosos. Rev Bras Med Esporte. 2007;13(1):11-6. https://doi.org/10.1590/S151786922007000100004
20. Oliveira A, Araújo J, Severo M, Correia D, Ramos E, Torres D, et al. Prevalence of general and abdominal obesity in Portugal: comprehensive results from the National Food, nutrition and physical activity survey 2015-2016. BMC Public Health. 2018;18(1):614. https://doi.org/10.1186/s12889-018-5480-z

21. Silveira EAD, Vieira LL, Jardim TV, Souza JD. Obesity and its Association with Food Consumption, Diabetes Mellitus, and Acute Myocardial Infarction in the Elderly. Arq Bras Cardiol. 2016;107(6):509-17. https://doi.org/10.5935/abc.20160182

22. Stival M, Lima L, Karnikowski M. Hypothetical relationships between social determinants of health that influence on obesity in the elderly. Rev Bras Geriatr Gerontol. 2015;18(2):433-42. https://doi. org/10.1590/1809-9823.2015.14023

23. Silveira EA, Kac G, Barbosa LS. Obesity prevalence and associated factors in the elderly in Pelotas, Rio Grande do Sul State, Brazil: obesity classification according to two cutoff points for body mass index. Cad Saude Publica. 2009;25(7):1569-77. https://doi. org/10.1590/s0102-311 ×2009000700015

24. Queiroz BM, Silva Coqueiro R, Leal Neto JS, Borgatto AF, Barbosa $A R$, Fernandes MH. Physical inactivity among non-institutionalized elderly individuals: a population-based study. Ciênc Saúde Coletiva. 2014;19(8):3489-96. https://doi.org/10.1590/141381232014198.19882013

25. Ribeiro AQ, Salgado SML, Gomes IS, Fogal AS, Martinho KO, Almeida LFF, et al. Prevalence and factors associated with physical inactivity among the elderly: a population-based study. Rev Bras Ger Gerontol. 2016;19(3):483-93. https://doi.org/10.1590/1809-98232016019.150047

26. Pinho CPS, DinizAS, Anuda IKG, Batista Filho M, Coelho P, Sequeira LADS, et al. Prevalence of abdominal obesity and associated factors among individuals 25 to 59 years of age in Pernambuco State, Brazil. Cad Saude Publica. 2013;29(2):313-24. https://doi.org/10.1590/S0102-311X2013000200018

27. Wilmot EG, Edwardson CL, Achana FA, Davies MJ, Gorely T, Gray L), et al Sedentary time in adults and the association with diabetes, cardiovascular disease and death: systematic review and meta-analysis. Diabetologia. 2012;55(11):2895-905. https://doi. org/10.1007/s00125-012-2677-z

28. Bhurosy T, Jeewon R. Overweight and obesity epidemic in developing countries: a problem with diet, physical activity, or socioeconomic status? Sci World J. 2014;2014:964236. https:// doi.org/10.1155/2014/964236

29. Bherer L, Erickson KI, Liu-Ambrose T. A review of the effects of physical activity and exercise on cognitive and brain functions in older adults. J Aging Res. 2013;2013:657508. https://doi.org/10.1155/2013/657508

30. Kohl 3rd HW, Craig CL, Lambert EV, Inoue S, Alkandari JR, Leetongin G, et al. The pandemic of physical inactivity: global action for public health. Lancet. 2012;380(9838):294-305. https://doi.org/10.1016/S0140-6736(12)60898-8

31. Bloom EL, Farris SG, DiBello AM, Abrantes AM. Smoking-related weight and appetite concerns and use of electronic cigarettes among daily cigarette smokers. Psychol Health Med. 2019;24(2):221-8. https://dx.doi.org/10.1080\%2F13548506.2018.1537495

32. Gasperin LOF, Neuberger M, Tichy A, Moshammer H. Cross-sectional association between cigarette smoking and abdominal obesity among Austrian bank employees. BMJ Open. 2014;4(7):e004899. https://doi.org/10.1136/bmjopen-2014-004899

33. Watanabe T, Tsujino I, Konno S, Ito YM, Takashina C, Sato T, et al. Association between smoking status and obesity in a nationwide survey of Japanese adults. PloS One. 2016;1 1(3):e0148926. https:// dx.doi.org/10.1371\%2Fjournal.pone.0148926

34. Alves RFS, Faerstein E. Educational inequality in the occurrence of abdominal obesity: Pró-Saúde Study. Rev Saude Publica. 2015;49:65. https://doi.org/10.1590/S0034-8910.2015049005786

35. Nascimento GG, Leite FR, Conceição DA, Ferrúa CP, Singh A, Demarco FF. Is there a relationship between obesity and tooth loss and edentulism? A systematic review and meta-analysis. Obes Rev. 2016;17(7):587-98. https://doi.org/10.1111/obr.12418

36. Hilgert JB, Hugo FN, Sousa MLR, Bozzetti MC. Oral status and its association with obesity in Southern Brazilian older people. Gerodontology. 2009;26(1):46-52. https://doi.org/10.1111/j.1741-2358.2008.00226.x 